\title{
DSC and electrophoretic studies on protein denaturation of Anodonta woodiana (Lea, 1834)
}

\author{
Piotr Konieczny ${ }^{1} \cdot$ Jolanta Tomaszewska-Gras $^{1} \cdot$ Wojciech Andrzejewski ${ }^{2}$. \\ Beata Mikołajczak $^{3} \cdot$ Maria Urbańska $^{2} \cdot$ Jan Mazurkiewicz $^{2} \cdot$ Jerzy Stangierski $^{1}$
}

Received: 15 November 2015 / Accepted: 12 July 2016/Published online: 25 July 2016

(c) The Author(s) 2016. This article is published with open access at Springerlink.com

\begin{abstract}
The aim of this study was to examine the thermal denaturation properties of proteins from fresh and frozen pond mussels Anodonta woodiana by differential scanning calorimetry (DSC). The A. woodiana (Lea, 1834) mussels were collected from the bottom of a lake located in West Poland. Three parts of the mussel: adductor muscle (AM), foot muscle (FO) and part of internal organs (IO), were taken for analysis. The DSC technique was used to characterize the stability of the protein system, and SDSPAGE was applied for the separation and identification of proteins. Thermal analysis in all parts of the mussel revealed two main endothermic transitions: the first at $60-61{ }^{\circ} \mathrm{C}$ and the second at $69-70{ }^{\circ} \mathrm{C}$. Denaturation transition occurred in the temperature range from 42 to $76^{\circ} \mathrm{C}$. The highest enthalpy of denaturation was observed for FO and was $15.75 \mathrm{~J} \mathrm{~g}^{-1}$ (per $1 \mathrm{~g}$ of protein) and $14.01 \mathrm{~J} \mathrm{~g}^{-1}$ for AM. The lower-temperature peak, related to myosin and paramyosin, accounted for approximately $70-80 \%$ of the total area of transition. Electrophoretic analysis (SDSPAGE) confirmed that the paramyosin, with a mass of approx. 98-107 kDa, constituted the largest percentage, i.e., $24 \%$ in AM and $17 \%$ in IO and FO. Two other main
\end{abstract}

\section{Jolanta Tomaszewska-Gras}

gras@up.poznan.pl

1 Department of Food Quality Management, Faculty of Food Science and Nutrition, Poznan University of Life Sciences, Wojska Polskiego 31/33, 60-624 Poznan, Poland

2 Division of Inland Fisheries and Aquaculture, Faculty of Veterinary Medicine and Animal Science, Poznan University of Life Sciences, Wojska Polskiego 71C, 60-625 Poznan, Poland

3 Institute of Meat Technology, Faculty of Food Science and Nutrition, Poznan University of Life Sciences, Wojska Polskiego 31/33, 60-624 Poznan, Poland myofibrillar proteins were also present in significant amounts: myosin with a molecular mass of $230-245 \mathrm{kDa}$ (12-14\%) and actin with a mass of $47 \mathrm{kDa}(18-20 \%)$. In this study, the effect of freezing on protein stability was also investigated. The results of DSC analyses revealed that the process of freezing did not have a significant influence on the first and second peak temperature. Significant differences in enthalpy between fresh and frozen samples were observed only for AM, for which the total enthalpy $(\Delta H)$ decreased by $33 \%$. This study provided insight into the biochemistry of $A$. woodiana meat and offers an area of scientific novelty. Recognizing quality properties of meat tissue from freshwater Chinese pond mussels collected from selected water ecosystems seems to be important with respect to the potential possibility of using it for feed, pet food or even in food products.

Keywords Mussel $\cdot$ Anodonta woodiana . Thermal stability $\cdot$ DSC $\cdot$ SDS-PAGE

\section{Introduction}

In the face of global deficiencies of foods rich in proteins, studies are needed on the search for new materials for food or feed purposes. Bivalves such as clams, mussels and oysters offer good sources of protein, glycogen and minerals, are easily digestible and compare favorably with other animal foods [1]. Additionally, various physiological functions and health-promoting properties of clams have been recognized [2]. There is a potential for extracts of their soft tissues to be used as an antifungal, antibacterial or even antitumor agent [3, 4].

The Anodonta woodiana is an edible mussel with the common Chinese name He Bang. Among bivalves, it is 
known as an invasive species transported with fish shipments and penetrated from Asia not only the American continent but also Europe. Following numerous studies, both marine and freshwater A. woodiana may constitute safe biomaterial of potential processability $[3,5,6]$. Evaluation of the possibility to use them requires extensive and multidirectional studies including the studies of the functional properties of proteins, i.e., those physicochemical properties that influence the behavior of proteins during processing, storage and feed/food consumption [7].

Differential scanning calorimetry (DSC) is a very useful tool for studying the thermal properties of proteins, especially in terms of the denaturation process $[8,9]$. When a sample rich in proteins is heated by a programmed heating rate, endothermic peaks appear, whose area can act as a measurement of the stability of the protein. This can be characterized by the following DSC parameters: the heat absorbed $(\Delta H)$, the temperature at which the peak starts to be deflected from the baseline, determined by extrapolation (onset temperature, $T_{\mathrm{o}}$ ), and the temperature at which the peak reaches a maximum (peak temperature, $T_{\mathrm{p}}$ ). There are some factors that influence the peak temperature $T_{\mathrm{p}}$, such as heating rate, protein concentration and sample size [10]; hence, it is important to keep these variables constant to obtain reproducible results. This technique allows protein behavior to be studied in situ in very small amounts. DSC was widely used to analyze the proteins of muscle tissue from chicken, beef, pork and fish meat $[11,12]$. The DSC studies characterizing the thermal properties of muscle proteins in squid (Illex argentinus) [13] or scallop (Zygochlamys patagonica) [14] were reported. However, little DSC research has been done on muscle proteins from other marine or freshwater sources. Thus, the aim of this study was to examine the protein composition and thermal stability of fresh and frozen muscles of the edible mussel A. woodiana by using electrophoresis and differential scanning calorimetry.

\section{Materials and methods}

\section{Materials}

The A. woodiana (Lea, 1834) mussels were collected from bottom of a lake located in West Poland. Experiment has been done in two sets. As shown in Fig. 1, in each set three mussels were taken, and from each mussel three parts were cut for analysis: the adductor muscle (AM), foot muscle (FO) and part of internal organs (IOs). Samples were chilled and stored at $4{ }^{\circ} \mathrm{C}$ in refrigerator until analysis. Additionally, samples of three parts of mussel mentioned above were frozen at $-18{ }^{\circ} \mathrm{C}$ and stored for 1 month. After this period, samples were thawed and analyzed by DSC for protein stability.

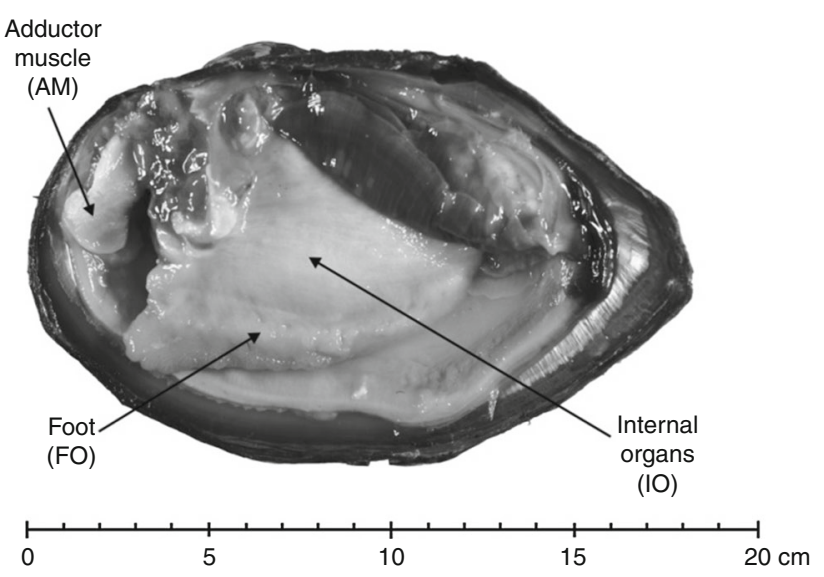

Fig. 1 A. woodiana (LEA, 1834): adductor muscle (AM), foot muscle (FO) and internal organs (IO)

\section{Sodium dodecyl sulfate-polyacrylamide gel electrophoresis (SDS-PAGE)}

The sample of $10 \mathrm{mg}$ of raw material was mixed with a $150 \mu \mathrm{L}$ buffer (pH 6.8; $8 \mathrm{M}$ urea, $2 \mathrm{M}$ thiourea, $0.05 \mathrm{M}$ Tris-HCl, 0.075 M DTT, $3 \%$ (w/v) SDS, $0.05 \%(w / v)$ bromophenol blue). Each sample was heated for 3 min at $100{ }^{\circ} \mathrm{C}$. The protein concentration in $10 \mu \mathrm{L}$ samples was determined using a 2-D Quant Kit (GE Healthcare BioSciences). Electrophoretic analysis (SDS-PAGE) was conducted in $15 \%$ polyacrylamide gel [15]. The gels were prepared in triplicate. The separation of proteins was performed using two-phase gels: resolving and stacking gel. First, the $15 \%$ resolving gel was prepared $(30 \%(w / v)$ acrylamide, $75 \%(\mathrm{v} / \mathrm{v})$ glycerol; $3 \mathrm{M}$ Tris, $\mathrm{pH} 8.8 ; 10 \%$ (w/v) SDS; $1 \%(\mathrm{w} / \mathrm{v})$ ammonium persulfate; TEMED $16 \mu \mathrm{L}$ polyacrylamide gels. After resolving gel polymerization, the stacking gel $(10 \%(\mathrm{w} / \mathrm{v})$ acrylamide, $5 \%(\mathrm{v} / \mathrm{v})$ glycerol, $0.125 \mathrm{M}$ Tris (pH 6.8), distilled water, $10 \%$ (w/ v) SDS, $1 \%(\mathrm{w} / \mathrm{v})$ ammonium persulfate, staining buffer, TEMED) was poured on the layer of resolving gel. All gels were prepared using $80 \times 100 \mathrm{~mm}$ plates with $0.75-\mathrm{mm}$ spacers. The amount of proteins loaded into separate wells in each sample was $12 \mu \mathrm{g}$. Separation was conducted at room temperature in the vertical system using the SE 250 type apparatus (Hoefer Scientific Instruments Company). Electrophoresis was run with a constant current of $20 \mathrm{~mA}$ per gel. Proteins were visualized by staining in $0.05 \%(\mathrm{w} /$ v) Coomassie Brilliant Blue R-250; $50 \%(\mathrm{v} / \mathrm{v})$ methanol solution; $10 \%(\mathrm{v} / \mathrm{v})$ acetic acid for $1 \mathrm{~h}$ and destained by diffusion in $10 \%(\mathrm{v} / \mathrm{v})$ methanol, $4.5 \%(\mathrm{v} / \mathrm{v})$ acetic acid for several hours. All the images of the gels were acquired using an Image Master ${ }^{\circledR}$ VDS Pharmacia Biotech imaging system and analyzed using the Image Master ${ }^{\circledR}$ 1D Elite v. 4.0 program. A PageRuler Plus Protein Ladder 10-250 kDa (Thermo Scientific) containing 9 proteins 
$(250,130,100,70,55,35,25,15,10 \mathrm{kDa})$ was used for molecular weight calibration.

\section{Differential scanning calorimetry}

The measurements were taken using a PerkinElmer DSC 7 device (PerkinElmer, Norwalk) equipped with a PerkinElmer Intra cooler II and Pyris software. Nitrogen (99.999\% purity) was the purge gas. The DSC calorimeter was calibrated for temperature and enthalpy using indium (m.p. $156.6{ }^{\circ} \mathrm{C}, \Delta H_{\mathrm{f}}=28.45 \mathrm{~J} \mathrm{~g}^{-1}$ ) and $n$-dodecane (m.p. $\left.-9.65{ }^{\circ} \mathrm{C}, \Delta H_{\mathrm{f}}=216.73 \mathrm{~J} \mathrm{~g}^{-1}\right)$. The samples of various parts of the mussel $(10 \mathrm{mg})$ were weighed $( \pm 0.5 \mathrm{mg})$ into $20 \mu \mathrm{L}$ aluminum sample pans (PerkinElmer, No. 0219-0062) and sealed. At least three samples were heated from 5 to $95{ }^{\circ} \mathrm{C}$ at a scanning rate of $5{ }^{\circ} \mathrm{C} \mathrm{min}{ }^{-1}$ with a sealed empty pan as reference. The peak temperatures $\left(T_{\mathrm{p}}\right)$ were recorded, and the transition enthalpy $(\Delta H)$ was calculated from the peak area using the Pyris software and expressed in $\mathrm{J}$ per $1 \mathrm{~g}$ of sample material and in $\mathrm{J}$ per $1 \mathrm{~g}$ of protein. Protein analyses were performed by the Kjeldahl procedure using the Kjeltec system. A factor of 6.25 was used to calculate protein content.

The DSC curves of all samples investigated were fitted and deconvoluted by the Origin PeakFit module (OriginLab Corporation, Northampton, MA, US).

\section{Microscopy analysis}

A 5- $\mu$ m-thick paraffin slices were stained according to Masson-Gold procedure. The observations were conducted using an Axioscope light microscope in the Department of Animal Histology and Embryology of Poznań University of Life Sciences.

\section{Statistical analysis}

DSC and SDS-PAGE analyses were carried out at least in three repeats. Mean values and standard deviations (SD) were calculated. The analysis of variance (ANOVA) was applied to determine the significance of variability factors on the effect measured. Tukey's post hoc test was used for group mean comparisons. Differences were found to be significant at $p \leq 0.05$. Statistical treatment of the data was performed using Statistica 10.

\section{Results and discussion}

Three parts of the $A$. woodiana mussel: the adductor muscle (AM), foot muscle (FO) and internal organs (IO), were taken for this study. A microscopy picture of the adductor and foot muscle taken for analysis is shown in Fig. 2. DSC denaturation curves of three parts (AM, FO and IO) are presented in Fig. 3 together with a denaturation curve of chicken breast muscle for comparison. The muscle tissue of vertebrates (for example, chicken muscles) is a complex system comprising three classes of protein: myofibrillar, sarcoplasmic and connective tissue; hence, the DSC curve is also a complex transition composed of at least three peaks. In the DSC studies on the muscle tissue of vertebrates [10,11], the following assignment of peaks is given: The first peak, at a low temperature, is linked to myosin and related proteins, the last one at a higher temperature is associated with actin, and the peaks between are related to sarcoplasmic proteins and collagen as shown for chicken breast muscle in Fig. 3. Thermal analysis of three parts of fresh A. woodiana (AM, IO and FO) revealed two main endothermic transitions: the first at around $60-61{ }^{\circ} \mathrm{C}$ and the second at approx. $69-70{ }^{\circ} \mathrm{C}$. We may notice that the traces presented have some specific features. All samples exhibit a very pronounced, relatively sharp peak at around $60-60{ }^{\circ} \mathrm{C}$. Traces of the adductor and foot muscles show two distinct peaks, whereas for the other sample IO in the higher-temperature region, the curve is falling down without any visible peaks. On the lower-temperature side of the main peak, all curves show more or less pronounced shoulders. The denaturation transition occurred in a temperature range from 45 to $76{ }^{\circ} \mathrm{C}$. The differences observed in DSC traces between chicken breast muscle and the $A$. woodiana mussel arise from the fact that this mussel is an invertebrate; thus, we may expect that its protein structure will be different. According to Paredi et al. [16], peak with a maximum at around $60-61{ }^{\circ} \mathrm{C}$ corresponds to myosin and paramyosin, and the second peak is related to the next myofibrillar protein, actin. Kantha et al. [17] similarly stated that except for myosin and actin, muscles of marine invertebrates contain one more characteristic protein, namely paramyosin. This is a fibrous protein found in the phyla Platyhelminthes, Nematoda, Nematomorpha, Annelida, Mollusca, Arthropoda and Echinodermata. Paramyosin is a significant protein component in the muscles of edible molluscs and arthropods [17]. It has been reported that paramyosin alters the characteristic texture of marine meat gel products considerably. The gel properties of surimi made from Alaskan pollock Theragra chalcogramma gels increased with a 15-25\% increase in paramyosin contents [18]. Despite this abundance and a great deal of research on the biochemistry of the catch contraction mechanism of adductor muscles, paramyosin has not attracted the attention of the food chemists that it deserves. The contribution of paramyosin to the surimi gel characteristics and to seafood systems in general needs to be investigated in detail. The importance of paramyosin to the quality of seafood systems should be studied further.

The stability of a structure composed of proteins can be studied by using DSC curves to calculate the thermotropic 
Fig. 2 Microscopy pictures of $\mathbf{a}$ adductor and $\mathbf{b}$ foot muscles (a)

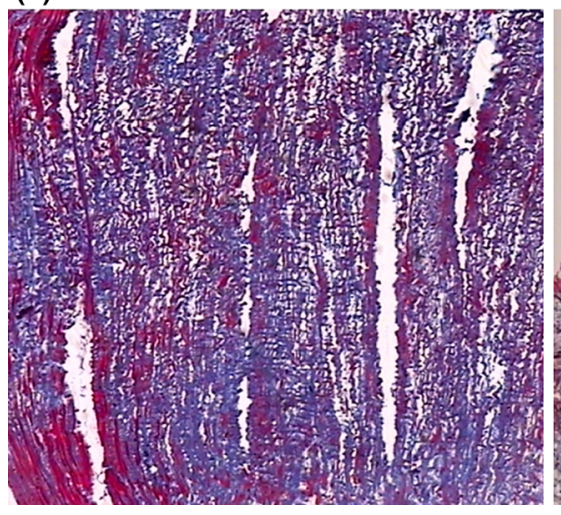

(b)

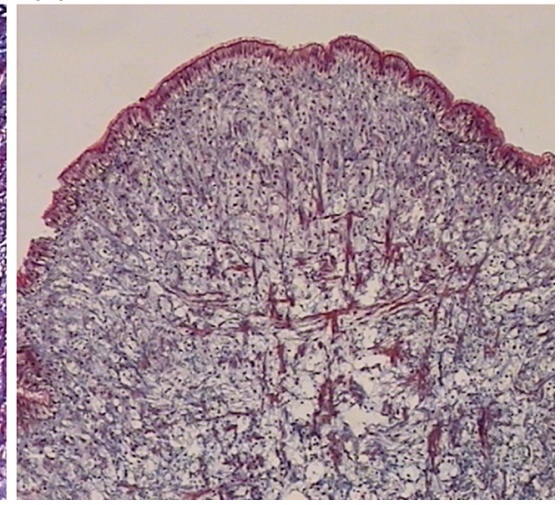

Fig. 3 DSC denaturation curves of three parts of the $A$. woodiana mussel (LEA, 1834): adductor muscle, foot muscle, internal organs. Chicken breast muscle is shown as an example of striated muscle

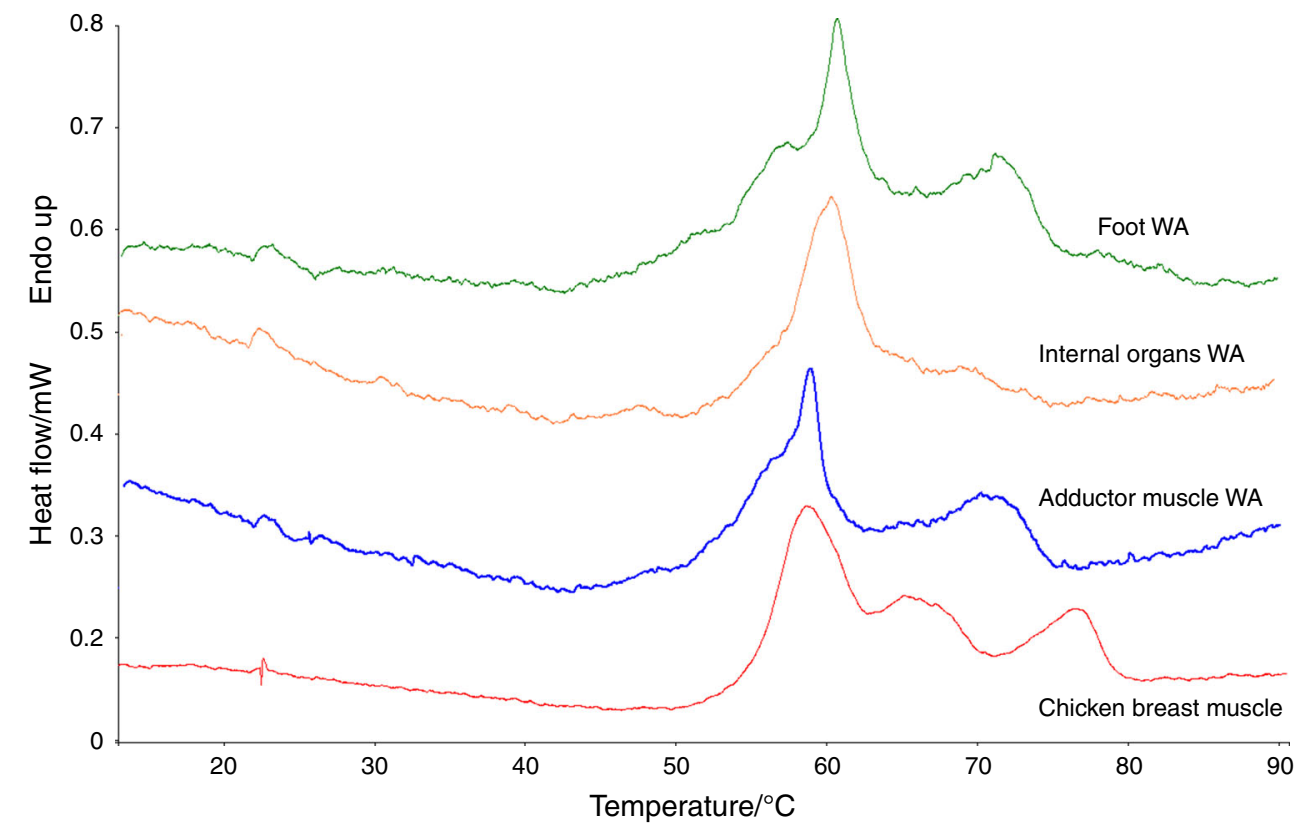

parameters as temperatures and enthalpies of denaturation, which are presented in Table 1. No significant differences $(p>0.05)$ were found between the first peak temperatures $\left(T_{\mathrm{p}} 1\right)$ of all types of fresh muscles, whereas differences between the second peak temperatures $\left(T_{\mathrm{p}} 2\right)$ were significant. In the case of the denaturation enthalpies of three investigated fresh muscles (AM, FO and IO), significant differences were found $(p<0.05)$. The highest enthalpy of $15.75 \mathrm{~J} \mathrm{~g}^{-1}$ (per $1 \mathrm{~g}$ of protein) observed for the foot muscle (FO) and of adductor muscle (AM) amounted to $14.01 \mathrm{~J} \mathrm{~g}^{-1}$. For comparison, denaturation enthalpy of chicken breast muscle was determined at a level of $17.9 \mathrm{~J} \mathrm{~g}^{-1}$. In all cases, the first peak was much higher than the second one, and the area of the first peak was approximately $70-80 \%$ of the total area.
In order to estimate and compare the protein composition in mussel, proteins were separated by SDS-PAGE. Figure 4 demonstrates the electrophoretic patterns of three different samples of $A$. woodiana: adductor muscle (AM), internal organs (IO) and foot muscle (FO) and chicken breast muscle. Eleven bands of proteins for AM and FO samples and ten for the IO sample were identified, which correspond to proteins with a molecular weight between 228 and $13 \mathrm{kDa}$. The molecular weight and percentage content of each protein are listed in Table 2. The results of protein SDS-PAGE analysis showed that the main proteins identified in three samples of A. woodiana (AM, FO and IO) were as follows: myosin (224-228 kDa), paramyosin $(98-107 \mathrm{kDa})$ and actin $(46 \mathrm{kDa})$. Those three proteins constituted $50-56 \%$ of all proteins observed on the gel; 
Table 1 Denaturation temperatures and enthalpies of proteins of fresh and frozen Anodonta Woodiana

\begin{tabular}{|c|c|c|c|c|c|c|}
\hline & \multicolumn{3}{|c|}{ Denaturation temperatures of fresh muscles $/{ }^{\circ} \mathrm{C}$} & \multicolumn{3}{|c|}{ Denaturation temperatures of frozen muscles $/{ }^{\circ} \mathrm{C}$} \\
\hline & $T_{p} 1$ & $T_{\mathrm{p}} 2$ & Temperature range & $T_{\mathrm{p}} 1$ & $T_{\mathrm{p}} 2$ & Temperature range \\
\hline $\mathrm{AM}$ & $59.72^{\mathrm{aA}} \pm 0.81$ & $71.14^{\mathrm{aA}} \pm 0.53$ & $45.49-76.68$ & $60.17^{\mathrm{aA}} \pm 0.01$ & $70.77^{\mathrm{aA}} \pm 0.86$ & $44.87-75.54$ \\
\hline $\mathrm{IO}$ & $59.55^{\mathrm{aA}} \pm 0.97$ & $69.17^{\mathrm{bA}} \pm 0.04$ & $44,87-75.21$ & $60.28^{\mathrm{aA}} \pm 0.20$ & $71.52^{\mathrm{bB}} \pm 0.12$ & $42.75-76.11$ \\
\hline \multirow[t]{3}{*}{$\mathrm{FO}$} & $61.29^{\mathrm{aA}} \pm 0.27$ & $68.64^{\mathrm{bA}} \pm 0.91$ & $43.58-76.04$ & $60.78^{\mathrm{aA}} \pm 0.22$ & $71.23^{\mathrm{bB}} \pm 0.41$ & $46.97-76.68$ \\
\hline & \multicolumn{3}{|c|}{ Enthalpy of denaturation for fresh muscles $/ \mathrm{J} \mathrm{g}^{-1}$ protein } & \multicolumn{3}{|c|}{ Enthalpy of denaturation for frozen muscles $/ \mathrm{J} \mathrm{g}^{-1}$ protein } \\
\hline & $\Delta H$ & $\Delta H 1$ & $\Delta H 2$ & $\Delta H$ & $\Delta H 1$ & $\Delta H 2$ \\
\hline $\mathrm{AM}$ & $14.01^{\mathrm{bA}} \pm 0.28$ & $9.99^{\mathrm{bA}} \pm 0.24$ & $3.50^{\mathrm{bA}} \pm 0.39$ & $9.36^{\mathrm{aB}} \pm 1.44$ & $7.41^{\mathrm{aB}} \pm 1.21$ & $1.95^{\mathrm{aB}} \pm 0.28$ \\
\hline $\mathrm{IO}$ & $12.49^{\mathrm{bA}} \pm 0.37$ & $10.59^{\mathrm{bA}} \pm 0.75$ & $1.91^{\mathrm{abA}} \pm 0.38$ & $12.90^{\mathrm{bA}} \pm 2.48$ & $11.02^{\mathrm{bA}} \pm 2.18$ & $1.88^{\mathrm{aA}} \pm 0.32$ \\
\hline $\mathrm{FO}$ & $15.75^{\mathrm{aA}} \pm 1.48$ & $12.84^{\mathrm{aA}} \pm 1.35$ & $2,91^{\mathrm{aA}} \pm 0.13$ & $15.52^{\mathrm{cA}} \pm 0.95$ & $11.22^{\mathrm{bB}} \pm 1.24$ & $4.29^{\mathrm{bB}} \pm 0.48$ \\
\hline
\end{tabular}

Within each kind of muscles (fresh and frozen), distributions of results with different superscript letters A, B within a row are significantly different $p<0.05$

Within each kind of muscles (AM, IO, FM), distributions of results with different superscript letters a, b within a column are significantly different $p<0.05$

$A M$ adductor muscle, $I O$ internal organs, $F O$ foot muscle

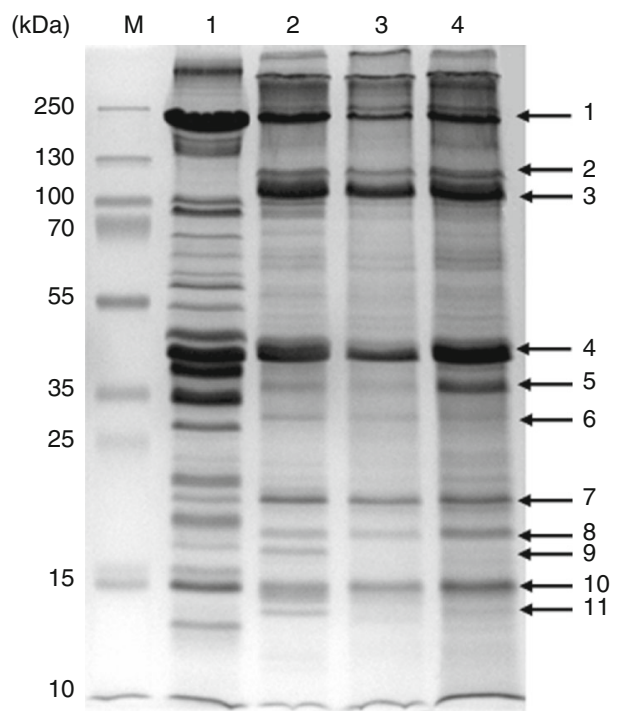

Fig. 4 Separation of proteins by SDS-PAGE (15\% separating gel). $M$ marker, 1 chicken breast muscle, 2 adductor muscle, 3 internal organs, 4 foot muscle

thus, we may suspect that they have the greatest influence on the DSC denaturation curve. Szent-Gyorgyi et al. [19] reported that a ratio of paramyosin/myosin greater than 1:1 is characteristic for smooth adductors.

As described by Szent-Gyorgyi et al. [19] and Elfvin et al. [20], in invertebrate muscles paramyosin constitutes the core of thick filaments, where it is covered by a cortical layer of myosin. Watabe et al. [21] reported that scallop adductor muscle is attached by a small piece of smooth muscle. This muscle, rich in paramyosin, is
Table 2 Characterization of proteins of Anodonta woodiana muscles separated by SDS-PAGE

\begin{tabular}{|c|c|c|c|c|}
\hline \multicolumn{2}{|c|}{ Proteins } & \multicolumn{3}{|c|}{ Share of proteins in muscle $/ \%^{a}$} \\
\hline No & $\mathrm{MW} / \mathrm{kDa}$ & $\mathrm{AM}$ & IO & FO \\
\hline 1. & $224-228$ & $14.27^{\mathrm{A}} \pm 0.39$ & $12.22^{\mathrm{B}} \pm 0.89$ & $13.15^{\mathrm{AB}} \pm 0.11$ \\
\hline 2. & $116-119$ & $5.02^{\mathrm{A}} \pm 0.96$ & $7.89^{\mathrm{B}} \pm 0.29$ & $6.33^{\mathrm{AB}} \pm 0.44$ \\
\hline 3. & $98-107$ & $24.01^{\mathrm{B}} \pm 0.40$ & $17.51^{\mathrm{A}} \pm 0.64$ & $16.97^{\mathrm{A}} \pm 0.10$ \\
\hline 4. & 46 & $17.89 \pm 0.34$ & $19.92 \pm 0.85$ & $19.41 \pm 1.42$ \\
\hline 5. & 38 & $6.14^{\mathrm{A}} \pm 0.23$ & $8.49^{\mathrm{B}} \pm 0.65$ & $10.94^{\mathrm{C}} \pm 0.71$ \\
\hline 6. & 30 & $5.18^{\mathrm{A}} \pm 0.55$ & $8.36^{\mathrm{B}} \pm 0.57$ & $4.01^{\mathrm{A}} \pm 0.67$ \\
\hline 7. & 20 & $8.89 \pm 0.76$ & $9.08 \pm 0.38$ & $8.46 \pm 0.24$ \\
\hline 8. & 18 & $4.20^{\mathrm{A}} \pm 0.39$ & $5.17^{\mathrm{B}} \pm 0.19$ & $6.61^{\mathrm{C}} \pm 0.46$ \\
\hline 9. & 17 & $4.23^{\mathrm{B}} \pm 0.15$ & not observed & $1.82^{\mathrm{A}} \pm 0.12$ \\
\hline 10. & 15 & $7.93^{\mathrm{B}} \pm 0.21$ & $9.38^{\mathrm{A}} \pm 0.34$ & $9.74^{\mathrm{A}} \pm 0.65$ \\
\hline \multirow[t]{3}{*}{11.} & 13 & $2.29 \pm 0.21$ & $1.99 \pm 0.08$ & $2.56 \pm 0.67$ \\
\hline & $\mathrm{M} / \mathrm{A}$ & 0.80 & 0.61 & 0.67 \\
\hline & $\mathrm{PM} / \mathrm{M}$ & 1.68 & 1.43 & 1.29 \\
\hline
\end{tabular}

A, B mean values in rows denoted by different letters differ statistically significant $(p \leq 0.05)$

$M W$ molecular weight, $A M$ adductor muscle, $I O$ internal organs, $F O$ foot muscle, $M / A$ myosin-to-actin ratio, $P M / M$ paramyosin-to-myosin ratio

${ }^{\text {a }}$ Mean value \pm standard deviation; $n=4$

believed to be involved in the catch mechanism of the scallop. It was also stated that the paramyosin content in smooth muscle is much greater than myosin content. DSC traces obtained with a wide range of transition and the results of electrophoretic separation indicate that 
denaturation of large proteins is a very complex process. It takes place in discrete stages, each of which corresponds to the breakdown of a definite domain. In order to get deeper insight into the composite character of the denaturation transition, we deconvoluted these DSC traces into six components, whose positions were rationalized by the path of each curve. The results are presented in Fig. 5, and they show the original trace, fitted peaks and cumulative convolution of fitted peaks. The calculated parameters of fitted peaks, especially the area under the peaks, which is related to the amount of protein, are in reasonable agreement with data obtained from electrophoretic analysis (Table 3). This figure indicates that the denaturation process of the sample occurs as a series of consecutive steps of denaturation for each specific protein. The main peaks, plotted with index 3 and 4 in Fig. 5a, accounted for $43.56 \%$ of the total area of adductor muscle transition (Table 3) and are probably related to the main proteins, i.e., myosin and paramyosin. Those two main peaks are similarly present in the IO and FO muscles, as shown in Fig. 5b, c. The last peak No. 6 with an area of $17.73 \%$ for AM, $13.75 \%$ for IO and $22.96 \%$ for FO corresponds to actin, according to Paredi et al. [16]. In turn, the peak No. 5 can be related to proteins with a low molecular weight (LMW) of between 38 and $13 \mathrm{kDa}$, because it is known that the second peak between myosin and actin in the chicken profile, as shown in Fig. 3, is related to LMW proteins [10]. Some relations can be found between the SDS-PAGE and DSC results. When compared to electrophoretic results (Table 2), myosin, paramyosin and actin content accounted for $56.17 \%$ for AM, $49.65 \%$ for IO and $49.53 \%$ for FO, whereas the percentage of the total area of the peaks for those three proteins, calculated from the deconvoluted peaks (Table 3), was $61.29 \%$ for AM, $68.13 \%$ for IO and $65.56 \%$ for FO.

In seafood, the functional properties (water holding capacity, gelation capacity, emulsification) are influenced by freezing and frozen storage; thus, the effect of 1-month frozen storage on protein stability was also investigated
Table 3 Area (\%) of deconvoluted peaks of DSC denaturation curves

\begin{tabular}{lccl}
\hline Peak index & AM & IO & FO \\
\hline 1 & 7.09 & 6.25 & - \\
2 & 8.32 & 8.75 & 8.53 \\
3 & 27.86 & 14.38 & 22.26 \\
4 & 15.70 & 40.00 & 20.34 \\
5 & 23.30 & 16.88 & 19.68 \\
6 & 17.73 & 13.75 & 22.96 \\
\hline
\end{tabular}

$A M$ adductor muscle, $I O$ internal organs, $F O$ foot muscle

[22]. The thermotropic results of DSC analyses are presented in Table 1 . These show that prolonged freezing did not have a significant influence on the denaturation temperature of the first and second peaks. However, significant differences in measured enthalpy between fresh and frozen samples were observed only for the adductor muscle. The total enthalpy $(\Delta H)$ of this sample decreased for frozen adductor muscle by $33 \%$. The decrease in enthalpy for the first peak $(\Delta H 1)$ and second peak $(\Delta H 2)$ was proportional and significant. These observations are consistent with the results presented by Paredi et al. [23], who reported that the adductor muscles of Zygochlamys are more sensitive to changes in the chemical environment. Differences observed in the thermal stability of the samples analyzed can be the result of varied water content in the three muscles. The adductor muscle contained the lowest amount of water $(79 \%)$ compared to IO (85\%) and FO (82\%) (unpublished data). H-bonding is known to be the main stabilizing force of protein structure; thus, freezing water molecules change the enthalpy factor due to dehydration of polar groups of proteins, leading to the destabilization of the protein structure and decreased stability at low temperatures. The lower enthalpy of the adductor muscle can also be the consequence of the proteolytic breakdown of myosin. Iguchi et al. [24] reported a decrease in the relative percentage of myosin with an increase in small proteolytic (a)

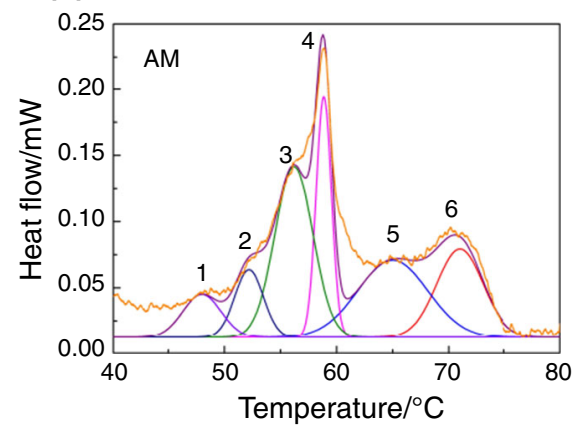

(b)

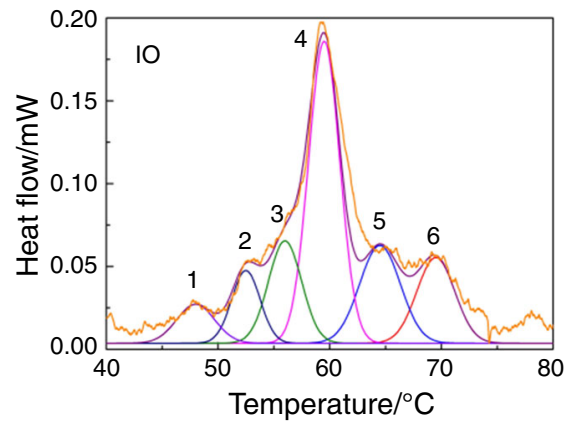

(c)

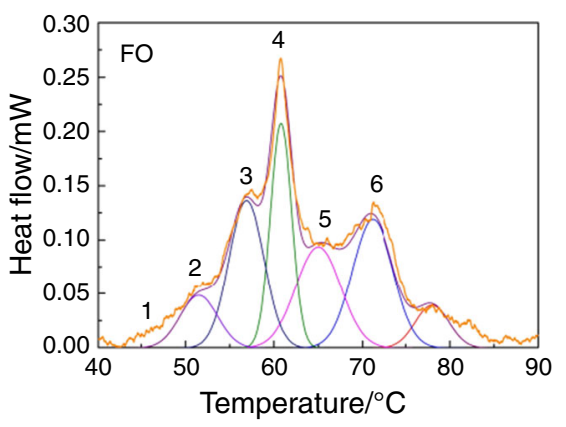

Fig. 5 Deconvolution of denaturation curves of adductor (AM), internal organs (IO) and foot muscle (FO) recorded by DSC 
fragments in frozen-stored AM from squid (O. sloani pacificus). In Fig. 3, a band with a small molecular weight of $17 \mathrm{kDa}$ is visible on the electrophoretic profile of the adductor muscle, which was not detected in the IO muscle. This can indicate that myosin in the AM and F muscles can be degraded by proteolytic enzymes. Konno et al. [25] also reported that myosin was the major target protein for proteinases and that the proteolytic activity remained unchanged during frozen storage.

\section{Conclusions}

DSC and electrophoretic measurements have shown that the most abundant protein in all parts of A. woodiana mussel investigated is not myosin but paramyosin, which comprises $17-24 \%$ of the total amount of proteins. In adductor muscle, the paramyosin content is much greater (24\%) than myosin content (14\%). According to DSC analysis on the stability of proteins, freezing did not have a significant influence on the first and second peak temperatures. The only significant differences between fresh and frozen tissue were observed for the total enthalpy of denaturation for adductor muscle. For the foot muscle and internal organs muscles, differences between fresh and frozen were not significant.

Acknowledgements The authors would like to thank Professor Hanna Jackowiak from the Department of Animal Histology and Embryology of Poznań University of Life Sciences for her help in doing microscopy analysis.

Open Access This article is distributed under the terms of the Creative Commons Attribution 4.0 International License (http://crea tivecommons.org/licenses/by/4.0/), which permits unrestricted use, distribution, and reproduction in any medium, provided you give appropriate credit to the original author(s) and the source, provide a link to the Creative Commons license, and indicate if changes were made.

\section{References}

1. Chinnamma G, Mathew PT. Biochemical and nutritional evaluation of yellow clams. Fish Technol. 1996;33:41-5.

2. Zeng Y, Yuping G, Wenjia H, Yuanxia S. Antioxidant peptides from freshwater clam extract using enzymatic hydrolysis. Afr J Food Sci. 2014;8:148-54.

3. Liu J, Gu B, Bian J, Hu S, Cheng X, Ke Q, Yan H. Antitumor activities of liposome-incorporated aqueous extracts of Anodonta woodiana (Lea, 1834). Eur Food Res Technol. 2008;227:919-24.

4. Seraspe EB, Abaracoso M. Screening of extracts of Diwal (Pholas orientalis) for antimicrobial activities. J Aquac Mar Biol. 2014;1:00002. doi:10.15406/jamb.2014.01.00002.

5. Urbańska M, Łakomy A, Andrzejewski W, Mazurkiewicz J. The story of one clam. Probably the oldest location of the Chinese pond mussel Sinanodonta woodiana (Lea, 1834) (Bivalvia, Unionidae) in Poland. Oceanol Hydrobiol Stud. 2012;41:41-5.
6. Andrzejewski W, Urbańska M, Mazurkiewicz J, Gierszal H, Golski J. The current invasion status of (Sinanodonta woodiana) (Lea, 1934) in Poland-study of habitat parameters. Oceanol Hydrobiol Stud. 2013;42:173-80.

7. Tomaszewska-Gras J, Konieczny P. Effect of marination on the thermodynamic properties of chicken muscle proteins studied by DSC. Czech J Food Sci. 2012;4:302-8.

8. Tamilmani P, Pandey MC. Thermal analysis of meat and meat products. J Therm Anal Calorim. 2016;123:1899-917. doi:10. 1007/s10973-015-4696-8.

9. Kamiyama T, Marutani T, Kato D, Hamada T, Kato K, Kimura T. Thermodynamic and kinetic properties of sorbitol-induced molten globule of myoglobin. J Therm Anal Calorim. 2016;123:1861-9. doi:10.1007/s10973-015-4767-x.

10. Wright DJ, Wilding P. Differential scanning calorimetry study of muscle and its proteins: myosin and its subfragments. J Sci Food Agric. 1984;35:257-72.

11. Xiong YL, Brekke CJ, Leung HK. Thermal denaturation of muscle proteins from different species and muscle types as studied by differential scanning calorimetry. Can Inst Food Sci. 1987;20:357-62.

12. Hastings RJ, Rodger GW, Park R, Matthews AD, Anderson EM. Differential scanning calorimetry of fish muscle: the effect of processing and species variation. J Food Sci. 1985;50:503-506 and 510 .

13. Paredi ME, Tomas MC, Crupkin M, Anon MC. Thermal denaturation of muscle proteins from male and female squid (Illex argentinus) at different sexual maturation stages. A differential scanning calorimetric study. J Agric Food Chem. 1996;44:3812-6.

14. Paredi ME, Tomas MC, Crupkin M. Thermal denaturation of myofibrillar proteins of striated and smooth adductor muscles of scallop (Zygochlamys patagonica). A differential scanning calorimetric study. J Agric Food Chem. 2002;50:830-4.

15. Fritz JD, Greaser ML. Changes in titin and nebulin in post mortem bovine muscle revealed by gel electrophoresis, western blotting and immunofluorescence microscopy. J Food Sci. 1991;56:607-10.

16. Paredi ME, Tomas MC, Crupkin M, Anon MC. Thermal denaturation of Aulacomya ater ater (Molina) myofibrillar proteins: a differential scanning calorimetric study. J Agric Food Chem. 1994;42:873-7.

17. Kantha SS, Watabe S, Hashimoto K. Comparative biochemistry of paramyosin—a review. J Food Biochem. 1990;14:61-88.

18. Sano T, Noguchi SF, Tsuchiya T, Matsumoto JJ. Contribution of paramyosin to marine meat gel characteristics. J Food Sci. 1986;51:946-50.

19. Szent-Gyorgyi AG, Cohen C, Kendrick-Jones J. Paramyosin and the filaments of molluscan "catch" muscles. Native filaments: isolation and characterization. J Mol Biol. 1971;56:239-58.

20. Elfvin M, Levine RJC, Dewey MM. Paramyosin in invertebrate muscles. I. Identification and localization. J Cell Biol. 1976;71:261-72.

21. Watabe S, Hartshorne DJ. Paramyosin and the catch mechanism. Comp Biochem Physiol. 1990;96:639-46.

22. Sikorski ZE. Protein change in muscle food due to freezing and frozen storage. Int J Refrig. 1978;1:173-80.

23. Paredi ME, Tomas MC, Crupkin M. Thermal behavior of myofibrillar proteins from the adductor muscles of scallops: a differential scanning calorimetric study (DSC). Braz J Chem Eng. 2003;20:153-9.

24. Iguchi SM, Tsuchiya T, Matsumoto JJ. Studies on the freeze denaturation of squid actomyosin. Bull Jpn Soc Sci Fish. 1981;47:1499-506.

25. Konno K, Young-Je C, Yoshioka T, Shinho P, Seki N. Thermal denaturation and autolysis profiles of myofibrillar proteins of mantle muscle of jumbo squid Dosidicus gigas. Fish Sci. 2003;69:204-9. 